\title{
A escrita pessoal do blog: sentidos sobre o bibliotecário*
}

\author{
Iara Vieira Mitre**
}

Resumo: Esse trabalho tem como objetivo refletir sobre a escrita pessoal do blog e apresentar recortes em que notamos a sua apropriação por parte de sujeitos bibliotecários, para rebater e refutar direta e particularmente o estereótipo persistente de sua imagem, materializado no discurso dominante, amplamente difundido, consolidado e regularizado.

Palavras-chave: escrita; blog; bibliotecário.

\section{A escrita pessoal na rede}

O termo blog consiste na junção das palavras "web" e "log", que se refere à "diário de bordo", visto que os blogs foram elaborados inicialmente para registro de navegação na rede eletrônica. Para permitir esses registros, os diários têm como características principais a facilidade de criação, manutenção, atualização e inserção de dizeres; a estrutura em "posts" em ordem decrescente de data, com referências sobre nome do autor, hora e data da escrita de cada bloco (ESCOBAR, 2007).

Os diários eletrônicos, entretanto, logo foram popularizados e ganharam força por se apresentarem, também, como um meio propício para registrar na rede as memórias e escritas dos internautas, que encontraram no blog um lugar para dizer de si, seja na perspectiva de uma elaboração intelectual, seja no âmbito profissional, ou ainda na divulgação de retratos pessoais, com questões particulares inviáveis de serem ditas em um contexto outro, vinculado a um lugar institucionalizado, dotado de regras, censuras, controles e padrões morais (RIBEIRO; SIQUEIRA; LACERDA, 2006).

O uso atribuído ao blog, portanto, o inscreve, tal qual o diário convencional e a autobiografia, no gênero das denominadas "escritas do eu", como são identificados os textos destinados a representar memórias particulares (KOMESU, 2004). O registro é atravessado pelo julgamento que o escritor faz de si, do outro e do objeto discursivo, ao considerar que seu texto tem por mérito a necessidade de institucionalizar-se como memória em um espaço que é público (SCHITTINE, 2004).

Tecidas essas considerações, que nos esclarecem a respeito das implicações do gênero textual do blog aos dizeres em questão, selecionamos recortes em que notamos a apropriação do blog, por parte de sujeitos bibliotecários para rebater e refutar direta e particularmente o estereótipo persistente de sua imagem, materializado no discurso dominante, amplamente difundido, consolidado e regularizado.

\footnotetext{
* Esse texto é um recorte do TCC "Sentidos sobre o bibliotecário: a imagem do profissional no ciberespaço" (2009).

** Bacharel em Ciências da Informação e da Documentação pela FFCLRP/USP. E-mail: iaramitre@gmail.com
} 


\section{ESTEREÓTIPO (IV)}

per a Nowbe | 16.07.08

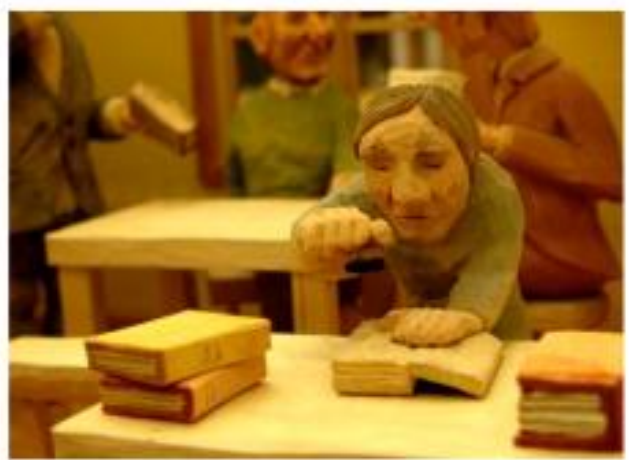

Serhorinha carimbendo tivros. Nais bibliotecárla, impossivel! @i (via Flicke)

COMENTE ESSE, ARTIGO

Figura 1 - Senhorinha carimbando livros.

Fonte: http://wl.blog.br/archives/category/imagem-do-bibliotecario. Acesso em: 18.set.2008.

O sujeito, ao utilizar-se da imagem da "Senhorinha carimbando livros", reforça o sentido cristalizado no imaginário popular e também sinaliza em seu dizer uma antecipação do bibliotecário, na condição de realizar um trabalho meramente mecânico, repetitivo e sem possibilidade de criatividade, o que nos é possível deduzir através de sua consideração na fala: "Mais bibliotecária, impossivvel!", seguida do ícone sorridente.

Assim, ao falar sobre o estereótipo, o sujeito situa-se, na repetição do efeito, que rotula o sujeito bibliotecário como profissional tecnicista e restrito ao trabalho mecânico e repetitivo, colocando-o marcado por uma imagem, cansada, curva e exaurida. Portanto, para o recorte em questão, o reconhecimento do estereótipo não consiste, senão, na manutenção, sob o disfarce do humor e do riso, dos sentidos atribuídos pelo discurso dominante ao sujeito bibliotecário. 


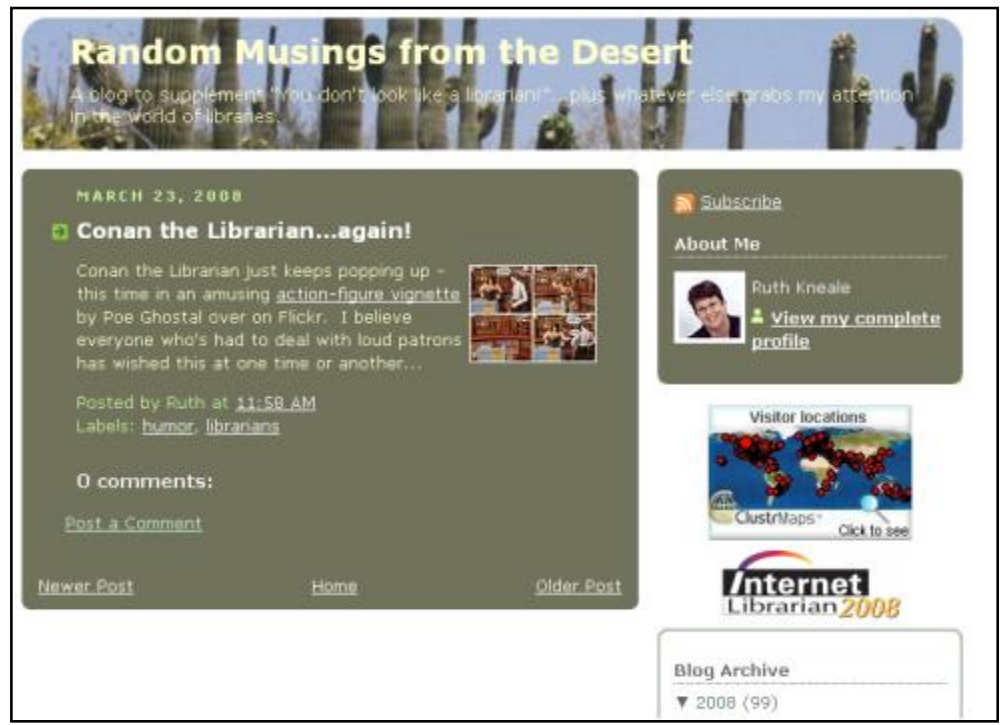

Figura 2 - Tira Cômica: Bibliotecário Conan ${ }^{4}$.

Fonte: http://desertlibrarian.blogspot.com/2008/03/conan-librarianagain.html. Acesso em: 13.jun.2008.

A vinheta do cartum que a bibliotecária indica, no post, enquadra-se em uma faceta do estereótipo, já que satiriza o profissional a partir de suas características conforme o estereótipo, no caso, autoritário, impondo o silêncio obrigatório. A partir do trecho: "Aposto que todos que já tiveram que lidar com clientes barulhentos já desejaram por isso pelo menos uma vez...", o sujeito inscreve-se na posição de representante dessa categoria prescrita pelo estereótipo, enquanto fala ao sujeito leitor de seu blog para situá-lo na mesma posição em concordância com essa postura satirizada, marcada na tira cômica.

Assim, é possível inferir que o blog é feito lugar de resistência, negação e tentativa de trazer à nota uma representação outra para o sujeito bibliotecário. Entretanto, notamos que a ideologia e a historicidade funcionam, na formação discursiva de resistência, de modo a mantê-lo ocupado em responder estritamente à questão imagética, deixando o esclarecimento sobre sua ocupação e função social em segundo plano.

\section{Referências}

\footnotetext{
${ }_{4}$ Texto traduzido: “Conan, o bibliotecário... outra vez! Conan o bibliotecário sempre aparece - desta vez em uma divertida vinheta de action figure por Poe Ghostal em Flickr. Aposto que todos que já tiveram que lidar com clientes barulhentos já desejaram por isso pelo menos uma vez...”.
} 
ESCOBAR, Juliana L. Blogs e interação mútua: uma visão contextualizada. In: Anais do XXX Congresso Brasileiro de Ciências da Comunicação. Santos, 2007. CDROM.

KOMESU, Fabiana C. Blogs e as práticas de escrita sobre si na Internet. In: RIBEIRO, M. A. P.; SIQUEIRA, Vera Helena Ferraz de; LACERDA, N. G. Gênero e tecnologia: os blogs como espaço de construção das identidades. In: Anais do Seminário Internacional Fazendo Gênero 7: Gênero e Preconceitos. Florianópolis/SC, 2006.

SCHITTINE, Denise. Blog: comunicação e escrita íntima na internet. Rio de Janeiro: Civilização Brasileira, 2004.

XAVIER, Antonio Carlos; MARCUSCHI, Luiz Antonio (orgs.). Hipertexto e gêneros digitais. São Paulo: Lucerna, 2004. 